\title{
Efisiensi dan Nilai Ekonomi Daging Sapi untuk Potongan Pasar Tradisional Berdasarkan Potongan Komersial yang Berbeda
}

\author{
Efficiency and Valuation of Beef Traditional Market Cuts Based on Different Types of Standard Commercial \\ Cuts
}

M. Baihaqi* \& E. L. Aditia

Departemen Ilmu Produksi dan Teknologi Peternakan, Fakultas Peternakan, Institut Pertanian Bogor

Jl. Agatis Kampus IPB Darmaga Bogor 16680 Indonesia

*Email koresponden author: baihaqi@apps.ipb.ac.id

(Received 23-04-2020; Revised 24-05-2020; Accepted 11-06-2020)

\begin{abstract}
Beef consumers in Indonesia are generally more familiar with the term of traditional processed meat such as rendang and semur compared to the standard commercial cuts. Those terms of beef cuts are usually used in meat trading as a communication language. The study aimed to evaluate the yield and economic value of traditional beef cuts including rendang, semur and tetelan derived from different types of standard commercial cuts. A total of $298.7 \mathrm{~kg}$ of beef consisting of 60 commercial cuts of topside and blade were used in this study. Each of commercial cuts was then broken down into common traditional common market name such as rendang, semur and tetelan cuts. The observed parameters consisted of the weights and percentages of the cuts and their economic values, including the cost of goods manufactured (COGM). The differences between topside and blade cuts in their yield and economic value were compared by t-test analysis using the $R$ statistical program version 4.0.0. The results showed that the weight of topside cut was significantly lower than that blade $(\mathrm{P}<0.05)$. However, the topside cut produced significantly higher amount and percentage of rendang and significantly lower amount and percentage of semur and tetelan compared to the blade $(\mathrm{P}<\mathbf{0 . 0 5})$. Economically, the value of blade cut was higher than that of topside for each $\mathrm{kg}$ of the traditional beef cuts (rendang, semur, tetelan) produced. It could, therefore, be concluded that the topside cut is economically more efficient than the blade in producing the traditional beef cuts.
\end{abstract}

Keywords: beef commercial cuts, economical value, efficiency

\begin{abstract}
ABSTRAK
Konsumen daging sapi di Indonesia umumnya lebih mengenal jenis dan nama potongan komersial daging sapi berdasarkan nama olahannya seperti daging rendang, semur, rawon dan tetelan dibandingkan dengan nama potongan komersial standarnya. Penelitian ini bertujuan untuk mengevaluasi efesiensi dan nilai ekonomi daging sapi potongan komersial untuk pasar tradisional seperti potongan daging rending, semur dan tetelan yang berasal dari jenis potongan komersial standar yang berbeda. Total $298.7 \mathrm{~kg}$ daging sapi yang terdiri dari 60 potongan komersial daging sapi bagian topside (penutup) dan blade (sampil kecil) digunakan pada penelitian ini. Masing-masing potongan komersial standar tersebut kemudian dipotong dan dibagi menjadi potongan sesuai nama umum dipasar yaitu potongan daging rendang, semur dan tetelan. Bobot masing-masing potongan komersial untuk tujuan pasar tradisional dan nilai ekonomi terutama harga pokok produksi (HPP) digunakan sebagai peubah. Data yang diperoleh dianalisa uji-t berdasarkan pelakuan dua jenis potongan komersial standar (blade dan topside) dengan menggunakan program statistic $R$ versi 4.0.0. Hasil penelitian menunjukkan bahwa potongan komersial standar nyata mempengaruhi jumlah daging baik untuk rendang dan semur yang dihasilkan $(\mathbf{P}<\mathbf{0 . 0 5})$. Potongan komersial standar topside menghasilkan jumlah dan persentase daging rendang yang nyata lebih tinggi dan daging semur yang lebih rendah dibandingkan dengan potongan standar blade. Secara ekonomi, nilai HPP potongan standar daging blade lebih tinggi dibandingkan dengan topside untuk setiap kg potongan daging standar pasar tradisional yang dihasilkan. Sehingga dapat disimpulkan bahwa penggunaan daging potongan standar topside untuk dijadikan sebagai daging potongan rendang dan semur lebih efesien dan ekonomis dibandingkan dengan potongan komersial standar daging blade.
\end{abstract}

Kata kunci: efesiensi, harga pokok produksi, potongan komersial daging sapi 


\section{PENDAHULUAN}

Daging merupakan salah satu produk hasil ternak utama yang diperlukan oleh masyarakat untuk memenuhi kebutuhan pangan. Konsumsi daging masyarakat akan semakin meningkat seiring dengan peningkatan taraf pendapatannya (Cirera \& Masset 2010). Seiring dengan permintaan daging tersebut, populasi sapi dalam negeri juga mengalami peningkatan dari tahun ke tahun. Tercatat pada tahun 2018 populasi sapi potong dalam negeri sebanyak 16433000 yang meningkat dari 16429000 pada tahun sebelumnya (DPKH 2019). Meskipun terjadi peningkatan populasi, kebutuhan daging sapi di dalam negeri masih tidak bisa dipenuhi seluruhnya dari produksi dalam negeri, sehingga pemerintah melakukan impor daging dalam bentuk ternak hidup maupun daging beku. Pada tahun 2017 defisit kebutuhan daging sapi dalam negeri mencapai 216.826 ton dan meningkat menjadi 261330 ton di tahun 2018 (DPKH 2019). Hal ini tentu mengharuskan pemerintah mendatangkan daging impor dari luar negeri untuk memenuhi kebutuhan masyarakat.

Daging sapi impor umumnya didatangkan dalam bentuk karkas maupun daging beku dari negara-negara produsen daging sapi seperti Australia dan Selandia Baru. Daging tersebut di negara asalanya dipotong menjadi potongan komersial, menggunakan standar negara masingmasing seperti Australian Meat and Livestock Corporation (1998). Klasifikasi potongan komersial yang ada primal cuts, secondary dan retail cuts. Namun pada kenyataanya, secara umum masyarakat di Indonesia belum begitu mengenal potongan komersial tersebut, meskipun sudah terdapat standar nasional Indonesia mengenai karkas dan daging sapi. Konsumen di pasar Tradisional lebih umum menggunakan istilah nama olahan untuk mengacu ke standar potongan komersial yang ada, seperti daging rendang, semur, tetelan dan lain-lain. Nama potongan daging rendang, semur, rawon dan tetelan menjadi nama yang umum di pasar tradisonal (standar potongan pasar tradisional). Penggunaan nama (brand) lokal sangat penting dalam pemasaran produk daging sapi (Schnettler et al. 2014).

Umumnya para pedagang daging sapi melakukan pemotongan daging beku impor dari potongan komersial ke bentuk ukuran dan berat yang lebih kecil untuk dijual kepada konsumen akhir. Beragam jenis potongan komersial daging sapi impor yang digunakan untuk menghasilkan potongan rendang, semur berasal dari potongan primal (primal cuts) baik dari paha belakang seperti topside (penutup), knuckle (kelapa), silverside (pendasar) dan rump (tanjung), serta dari bagian paha depan umumnya potongan blade (sampil kecil). Perbedaan masing-masing potongan komersial tersebut berimplikasi pada kualitas daging dan harganya (Polkinghorne \& Thompson 2010). Potongan blade umumnya mempunyai kualitas dan harga yang lebih rendah dibanding topside, karena mempunyai karakteristik keempukan, juiciness, aroma dan kesukaan yang berbeda (Legrand et al. 2013). Meskipun demikian pedagang melakukan pemotongan kedua jenis potongan komersial tersebut untuk menjadi potongan yang umum dikenal oleh konsumen lokal (rending dan semur) dan dijual dengan harga yang sama, tanpa memperhatikan asal potongan komersial tersebut. Menggunakan logika berfikir demikian, pedagang umumnya beranggapan bahwa daging rendang atau semur yang berasal dari potongan komersial blade mempunyai harga pokok produksi (HPP) lebih rendah dibandingkan dengan topside karena mempunyai harga bahan baku yang lebih murah sehingga efisien digunakan sebagai bahan baku untuk potongan rendang dan semur. Meskipun demikian, belum ada penelitian yang mencoba menghitung efesiensi dari penggunaan kedua jenis potongan komersial standar tersebut untuk dijadikan sebagai potongan daging yang menjadi standar di pasar tradisional. Berdasarkan hal tersebut, tujuan penelitian ini adalah mengevaluasi efesiensi dan nilai ekonomi daging sapi untuk potongan pasar tradisional (potongan rendang, semur, tetelan) yang diperoleh dari potongan komersial standar yang berbeda.

\section{MATERI DAN METODE}

\section{Waktu dan Lokasi Penelitian}

Penelitian ini dilakukan di Laboratorium Ruminansia Besar, Divisi Produksi Ternak Daging Kerja dan Aneka Ternak, Departemen Ilmu Produksi dan Teknologi Peternakan, Fakultas Peternakan, Institut Pertanian Bogor. Penelitian dilaksanakan pada tanggal 10-15 Mei 2020.

\section{Bahan dan Alat}

Penelitian ini menggunakan sebanyak $298.7 \mathrm{~kg}$ daging sapi yang terdiri dari 60 potongan komersial daging sapi bagian blade dan topside dengan rataan bobot masingmasing adalah $5.53 \pm 0.43$ dan $4.82 \pm 0.47 \mathrm{~kg}$, yang umumnya berasal dari spesies Bos taurus seperti sapi Hereford dan Angus yang dipelihara di padang penggembalaan (grassfed beef). Semua sampel merupakan potongan komersial daging sapi yang diimpor dari Selandia Baru. Alat yang digunakan pada penelitian ini meliputi: gergaji mesin pemotong daging, pisau, timbangan dan alat tulis.

\section{Prosedur}

Daging sapi potongan komersial blade dan topside dalam bentuk beku masing-masing dibeli dari importir daging yang dilapisi dengan plastik dan kemasan kotak karton. Satu kotak karton terdiri dari 4-5 potongan komersial. Masing-masing potongan komersial daging kemudian ditimbang untuk mengetahui bobot awal daging sebelum dipotong-potong menjadi potongan tradisional pasar.

Potongan tradisional pasar yang dibuat pada penelitian ini yaitu potongan rendang dan potongan semur. Tiap potongan komersial daging dipisahkan dengan lemak yang menempel utamanya lemak subkutan untuk mendapatkan tiap potongan tradisional pasar tersebut. Pemotongan dilakukan di ruangan dengan suhu rendah $( \pm 20$ ${ }^{\circ} \mathrm{C}$ ) untuk menghindari mencairnya daging beku selama proses pemotongan. Tahapan pada penelitian ini yaitu:

1. Identifikasi potongan komersial daging, dengan melakukan identifikasi dari identitas produk yang tertulis di karton mengenai jenis potongan komersial tersebut serta mencocokkan dengan karakteristik potongan komersial yang ada di standar (Australian Meat and Livestock Corporation 1998) 
2. Penimbangan bobot awal. Dilakukan pada masingmasing potongan komersial dan dicatat pada alat tulis.

3. Pemotongan daging menjadi potongan umum di pasar (rendang, semur dan tetelan). Pemotongan dilakukan dengan menggunakan mesin gergaji khusus untuk memotonga daging dan tulang (band saw). Tiap potongan disesuaikan dengan standar potongan yang umum dijual di pasar. Potongan rendang umumnya merupakan daging tanpa lemak (lean), sedangkan potongan semur umumnya merupakan daging dengan sedikit lemak yang menempel pada daging tersebut. Sedangkan tetelan yaitu sisa hasil pemisahan lemak dengan daging (trimming) yang sebagian besar merupakan lemak sub-kutan dan lemak intermuscular.

4. Penimbangan bobot potongan tradisional pasar. Setelah pemisahan dan pengelompokkan daging sesuai dengan potongan umum di pasar selesai, dilakukan penimbangan pada masing-masing potongan guna mengetahui berapa berat daging yang dihasilkan dari tiap sampel potongan komersial (blade dan topside).

\section{Peubah yang diamati}

Peubah yang diamati pada penelitian ini yaitu:

1. Bobot awal; yaitu bobot potongan komersial sebelum dipisahkan menjadi potongan rendang, semur atau tetelan.

2. Bobot dan persentase potongan rendang; yaitu bobot/persentase potongan daging sapi tanpa lemak (lean) sesuai dengan kriteria potongan rendang yang ada di pasar.

3. Bobot dan persentase potongan semur; yaitu bobot/ persentase potongan daging sapi dengan sedikit lemak yang menyertai sesuai dengan kriteria potongan semur yang umum di pasar.

4. Bobot dan persentase potongan tetelan; yaitu bobot/persentase hasil trimming (pemisahan) daging dengan lemak yang sesuai dengan kriteria tetelan di pasar.

5. Biaya beli, biaya penyusutan, biaya tenaga kerja dan biaya lain-lain merupakan biaya yang dikeluarkan untuk setiap $\mathrm{kg}$ masing-masing potongan komersial.

6. Harga Pokok Produksi dihitung berdasarkan variable costing yang merupakan penjumlahan dari biaya beli, biaya tenaga kerja dan biaya variable (biaya penyusutan, biaya lain-lain) pada tiap $\mathrm{kg}$ daging potongan komersial (Mulyadi 2012).

\section{Analisa Data}

Data yang diperoleh pada penelitian ini dianalisa menggunakan uji-t berdasarkan dua perlakuan jenis potongan komersial yang berbeda (blade dan topside). Selang kepercayaan yang digunakan adalah 95\%. Rumus matematika yang digunakan adalah sebagai berikut (Walpole 2005):

$$
\mathrm{T}=\frac{\mathrm{Xa}-\mathrm{Xb}}{\mathrm{Sp}\left[\left(\frac{1}{n a}\right)+\left(\frac{1}{n b}\right)\right]^{\frac{1}{2}}}
$$

Keterangan :

$$
\begin{array}{ll}
\mathrm{T} & =\text { Nilai } \mathrm{t} \\
\mathrm{Xa} & =\text { Rata-rata perlakuan potongan Blade; } \\
\mathrm{Xb} & =\text { Rata-rata perlakuan potongan Topside; } \\
\mathrm{Sp} & =\text { Standar deviasi gabungan; } \\
\mathrm{na} & =\text { Banyaknya sampel di perlakuan Blade; dan } \\
\mathrm{nb} & =\text { Banyaknya sampel di perlakuan Topside. }
\end{array}
$$

Data bobot dan persentase rendang, semur dan tetelan dianalisa menggunakan uji-t dengan aplikasi program statistik R versi 4.0.0 (2020-04-24) (R Core Team 2020). Analisa ekonomi dan harga pokok produksi dihitung berdasarkan variable costing yang merupakan penjumlahan dari biaya beli, biaya tenaga kerja dan biaya variable (biaya penyusutan, biaya lain-lain) pada tiap $\mathrm{kg}$ daging potongan komersial, selanjutnya harga pokok penjualan diperoleh dengan membandingkan total seluruh biaya dengan total volume produk yang dihasilkan (Mulyadi 2012).

\section{HASIL DAN PEMBAHASAN}

\section{Bobot dan Persentase Potongan Standar Daging Sapi untuk Pasar Tradisonal}

Potongan standar daging sapi untuk pasar tradisional merupakan potongan yang umum dikenal masyarakat di Indonesia, seperti potongan rendang, semur, rawon dan tetelan. Berdasarkan hal tersebut, masyarakat pada umumnya menggunakan nama-nama tersebut untuk klasifikasi jenis dan harga daging sapi. Nama-nama tersebut digunakan oleh pedagang untuk komunikasi jenis daging sapi yang dijual kepada masyarakat. Potongan tersebut umumnya didapat oleh pedagang dengan memotongnya dari potongan komersial daging impor yang diperoleh dalam bentuk per satuan potongan komersial. Setiap jenis potongan komersial dibungkus dengan karton dan diberi label identitas jenis potongan komersial serta informasi penting lainnya terkait asal daging tersebut dan lainnya. Hal ini dilakukan untuk mempermudah handling dan identifikasi jenis potongan komersial yang ada. Selanjutnya potongan komersial tersebut oleh pedagang akan dipotong dalam bobot lebih kecil menjadi potongan rendang, semur, rawon dan tetelan. Pada saat pemotongan tersebut, umumnya akan dipisahkan daging dengan lemak dan jaringan ikat yang disesuaikan dengan kriteria jenis potongannya. Proses tersebut menyebabkan bobot daging akan mengalami penyusutan dari bobot awal potongan komersial karena adanya trimming dan lainnya. Bobot potongan daging rendang, semur dan tetelan Berdasarkan potongan komersial yang berbeda dapat dilihat pada Tabel 1 .

Potongan komersial yang berbeda mempengaruhi jumlah bobot daging rendang, semur dan tetelan yang dihasilkan $(\mathrm{P}<0.05)$. Potongan blade mempunyai bobot lebih tinggi dibandingkan potongan topside. Hal ini sejalan dengan penelitian Muchakilla et al. (2014) yang memperoleh bobot potongan blade yang nyata lebih tinggi dibandingkan topside. Potongan topside menghasilkan jumlah daging 
Baihaqi et al.

Jurnal Ilmu Produksi dan Teknologi Hasil Peternakan 8 (2): 86-90

Tabel 1. Bobot Potongan Daging Rendang, Semur dan Tetelan Berdasarkan Potongan Komersial yang Berbeda

\begin{tabular}{llllc}
\hline Jenis potongan komersial & \multicolumn{4}{c}{ Bobot $(\mathrm{kg})$} \\
\cline { 2 - 5 } & Bobot awal & Rendang & Semur & Tetelan \\
\hline Blade & $5.53 \pm 0.43 \mathrm{a}$ & $1.37 \pm 0.10 \mathrm{~b}$ & $3.63 \pm 0.28 \mathrm{a}$ & $0.53 \pm 0.04 \mathrm{a}$ \\
Topside & $4.82 \pm 0.47 \mathrm{~b}$ & $2.87 \pm 1.02 \mathrm{a}$ & $1.77 \pm 1.15 \mathrm{~b}$ & $0.18 \pm 0.01 \mathrm{~b}$ \\
\hline
\end{tabular}

Keterangan: huruf yang berbeda pada kolom yang sama menunjukkan berbeda nyata $(\mathrm{P}<0.05)$

untuk rendang nyata lebih banyak dibandingkan dengan potongan blade $(\mathrm{P}<0.05)$ dan sebaliknya potongan blade menghasilkan jumlah daging untuk semur dan tetelan yang lebih banyak dibandingkan potongan topside $(\mathrm{P}<0.05)$. Potongan komersial blade diperoleh dari paha depan (forequarter) bagian bahu (shoulder) yang mempunyai jaringan lemak dan jaringan ikat yang lebih tinggi (Prieto et al. 2018) sehingga setelah diurai, menghasilkan daging untuk rendang yang lebih sedikit.

Potongan daging untuk rendang merupakan jenis potongan yang umum dipasar tradisional dengan ciri utama yaitu lebih sedikit lemak. Proses pembuatan potongan ini yaitu dengan memisahkan jaringan lemak baik subkutan dan intermusculer yang menempel pada daging. Lemak intermuscular merupakan lemak yang ada diantara otot yang keberadaannya umum ada di bagian potongan komersial yang mempunyai jumlah otot yang lebih banyak seperti potongan blade dan mempengaruhi keempukan dagingnya (Belew et al. 2003). Hasil penelitian Priyanto et al. (2009) juga menyampaikan bahwa potongan blade mempunyai jumlah lemak intermuscular yang lebih tinggi dibandingkan dengan potongan topside.

Selain jumlah, persentase daging rendang yang dihasilkan oleh potongan topside nyata lebih tinggi dibandingkan blade $(\mathrm{P}<0.05)$. Tabel 2 menunjukkan bahwa persentase daging rendang yang dihasilkan oleh potongan topside sebanyak $60.30 \pm 22.32 \%$ lebih tinggi dibandingkan potongan blade yaitu $24.78 \pm 02.01 \%$. Sebaliknya persentase potongan daging semur pada potongan blade nyata lebih tinggi dibandingkan potongan topside $(65.60 \pm 04.60$ vs $35.87 \pm 22.45 \%$ ). Hal ini juga sejalan dengan hasil penelitian dari Priyanto \& Johnson (2012) yang menunjukkan bahwa pada sapi Hereford dan Brahman mempunyai berat lemak pada potongan komersial blade yansg relatih lebih tinggi jika dibandingkan dengan topside.

Potongan komersial topside diperoleh dari bagian paha belakang (hind quarter). Struktur otot pada topside umumnya mempunyai jaringan otot yang lebih sedikit jumlahnya yaitu terdiri dari otot bicep femoris, semi tendinous dan semitendinosus (Jeremiah et al. 2003).

Tabel 2.Persentase Potongan Daging Rendang, Semur dan Tetelan Berdasarkan Potongan Komersial yang Berbeda

\begin{tabular}{lccc}
\hline Jenis & \multicolumn{3}{c}{ Persentase (\%) } \\
\cline { 2 - 4 } $\begin{array}{l}\text { potongan } \\
\text { komersial }\end{array}$ & Rendang & Semur & Tetelan \\
\hline Blade & $24.78 \pm 02.01 \mathrm{~b}$ & $65.60 \pm 04.60 \mathrm{a}$ & $09.62 \pm 00.21 \mathrm{a}$ \\
Topside & $60.30 \pm 22.32 \mathrm{a}$ & $35.87 \pm 22.45 \mathrm{~b}$ & $03.82 \pm 00.12 \mathrm{~b}$ \\
\hline
\end{tabular}

Keterangan: huruf yang berbeda pada kolom yang sama menunjukkan berbeda nyata $(\mathrm{P}<0.05)$
Jenis otot ini mempunyai bentuk lebih besar, sehingga jaringan lemak intermuscular pada potongan komersial ini menjadi sedikit. Oleh karena itu, jumlah dan persentase untuk dijadikan sebagai daging rendang akan lebih tinggi dibandingkan dengan potongan blade. Holman \& Hopkins (2019) menyatakan bahwa daging potongan bolar blade lebih banyak kehilangan cairan selama pemasakan dibandingkan dengan daging topside dan striploin yang dilayukan (aging) selama 28 hari.

\section{Nilai Ekonomi dan Harga Pokok Produksi}

Beberapa pedagang daging menganggap bahwa menggunakan potongan daging blade untuk diurai menjadi daging rendang atau semur akan menghasilkan keuntungan yang lebih tinggi. Hal tersebut dikarenakan harga beli potongan komersial daging blade umumnya lebih murah dibandingkan daging topside. Daging potongan blade dan topside merupakan primal cuts dengan karakteristik yang berbeda, dimana potongan topside lebih lean dibandingkan blade, sehingga berimplikasi pada harga jual masingmasing potongan (Schnettler et al. 2014). Meskipun demikian, anggapan itu perlu dibuktikan, salah satunya dengan membandingkan harga pokok produksi (HPP) yang dihasilkan oleh tiap potongan komersial daging tersebut.

Tabel 3 menunjukkan bahwa daging yang dihasilkan oleh potongan komersial topside mempunyai HPP yang lebih rendah dibandingkan dengan potongan komersial blade. Meskipun harga awal daging potongan blade lebih rendah $\mathrm{Rp} 3.000 / \mathrm{kg}$ dibandingkan dengan topside. Namun setelah dilakukan penguraian menjadi daging rendang atau semur, mempunyai penyusutan yang lebih besar yaitu Rp 8 802/kg dibandingkan penyusutan daging topside Rp 3 610/kg sehingga hasil HPP daging dari blade lebih mahal dibandingkan dengan topside dengan selisih Rp 2 163/kg untuk masing-masing potongan komersial. Penyusutan merupakan komponen dalam perhitungan HPP yang merupakan lemak hasil trimming pada proses pembuatan daging untuk standar potongan pasar. HPP adalah mekanisme untuk menentukan harga batas jual kepada konsumen (Mulyadi 2012).

Berdasarkan Tabel 3 dapat dilihat bahwa daging topside mempunyai peluang untuk mendapatkan keuntungan lebih banyak jika dijadikan sebagai bahan baku pembuatan potongan untuk pasar tradisional dibandingkan potongan komersial blade. Hal ini akan berbeda jika pedagang langsung menjualnya dalam bentuk potongan komersial atau tanpa membuang lemak pada tiap potongan komersial tersebut.

Topside pada umumnya di negara-negara maju dijadikan sebagai bahan baku untuk memasak masakan roasting sementara blade dijadikan sebagai masakan dengan 
Tabel 3. Harga Pokok Produksi Daging Sapi Berdasarkan Potongan Komersial yang Berbeda

\begin{tabular}{|c|c|c|}
\hline \multirow[t]{2}{*}{ Komponen } & \multicolumn{2}{|c|}{ Biaya (Rp) } \\
\hline & Blade & Topside \\
\hline Harga beli & 91500 & 94500 \\
\hline Biaya Penyusutan & 8802 & 3610 \\
\hline Biaya Tenaga kerja & 1944 & 1944 \\
\hline Biaya Lain-lain & 915 & 945 \\
\hline HPP Daging & 103162 & 100999 \\
\hline
\end{tabular}

metode masak yang lebih lama seperti pan frying (MLA 2018). Namun hal ini berbeda untuk pasar tradisional di Indonesia yang umumnya menggunakan metode memasak yang lama, sehingga bahan baku daging dapat berasal dari beberapa jenis potongan komersial yang berbeda seperti potongan paha bekalang meliputi topside (penutup), knuckle (kelapa), silverside (pendasar) dan rump (tanjung), serta dari bagian paha depan yaitu potongan blade (sampil kecil), chuck (sampil besar) dan shank (sengkel).

\section{KESIMPULAN}

Berdasarkan hasil penelitian ini dapat disimpulkan bahwa perbedaan jenis potongan komersial standar menghasilkan jumlah daging untuk potongan rendang, semur dan tetelan yang berbeda. Penggunaan standar komersial potongan topside untuk dijadikan sebagai daging seperti rendang dan semur lebih efisien dan ekonomis dibandingkan dengan potongan blade.

\section{DAFTAR PUSTAKA}

Australian Meat and Livestock Corporation. 1998. Aus-Meat for Indonesia Workshop. Work Book No. 1. Australian Meat and Livestock Corporation. Perth Western Australia

Belew, J. B., J. C. Brooks, D. R. McKenna, \& J. W. Savell. 2003. Warner-Blatzer shear evaluation of 40 bovine muscle. Meat Sci. 64: 507-512

Cirrera, X., \& E. Masset. 2010. Income distribution trends and future food demand. Philos Trans R Soc Lond B Biol Sci. 365(1554): 2821-2834

DPKH (Direktorat Peternakan dan Kesehatan Hewan). 2019. Statistik Peternakan dan Kesehatan Hewan. Ditjend PKH, Kementerian Peternakan, RI, Jakarta.

Holman, B. W. B., \& D. L. Hopkins. 2019. Contrasting the quality traits of aged bolar blade, topside and striploin cut sourced from dark cutting and control Australian beef carcasses. Meat Sci. 149:24-30.
Jeremiah, L. E., M. E. R. Dugan, J. L. Aalhus, \& L. L. Gibson. 2003. Assessment of the chemical and cooking properties of the majorbeef muscles and muscle groups. Meat Sci. 65:985-992.

Legrand, I., J. F. Hocquette, R. J. Polkinghorne, \& D. W. Pethick. 2013. Prediction of beef eating quality in France using the Meat Standards Australia system. Animal. 7(3):524-529.

Meat and Livestock Australia. 2018. Meat Standard Australia: Beef Primar and Subprimar Cuts. Meat and Livestock Australia.

Muchakilla, M. B., L. Asimwe, A. E. Kimambo, L. A. Mtenga, \& G. H. Laswai. 2014. Effect of diet and muscle type on meat quality characteristics of Tanzania Shorthorn Zebu. Livestock Research for Rural Development. 26(10).

Mulyadi. 2012. Akuntansi Biaya Edisi 5. Universitas Gadjah Mada. Aditya Media. Yogyakarta.

Polkinghorne, R. J., \& J. M. Thompson. 2010. Meat standard and grading: a world review. Meat Sci. 86:227-235.

Prieto, N., O. Lopez-Campos., S. P. Suman., A. Rodaz-Gonzales, \& J. L. Aalhus. 2018. Exploring innovative possibilities of recovering the value of dark-cutting beef in the Canadian grading system. Meat Sci. 137:77-84.

Priyanto, R., E. R. Johnson, \& D. G. Taylor. 2009. The growth patterns of carcass tissues within wholesale cuts in fattening steer. Journal of the Indonesian Tropical Animal Agriculture. 34(2):153-158.

Priyanto, R., \& E. R. Johnson. 2012. The Growth and Distribution of Carcass Fat in Fattening Steer of Different Breeds. Media Pet. 45-48

R Core Team. 2020. R: A language and environment for statistical computing. R Foundation for Statistical Computing, Vienna, Austria. URL https://www.Rproject.org/.

Schnettler, B, N. Sepúlveda, J. Sepúlveda, L. Orellana, H. Miranda, Horacio, G. Lobos, \& M. Mora. 2014. Consumer preferences towards beef cattle in Chile: Importance of country of origin, cut, packaging, brand and price. Revista de la Facultad de Ciencias Agrarias, 46(1),143-160.

Walpole, R. E. 2005. Pengantar Statistika. PT Gramedia Pustaka Utama, Jakarta. 